\title{
旧城郭における明治以降の曲輪の変容の履歴 \\ 一城郭の境界性に関する研究（その1）- \\ THE DIACHRONIC CHANNELS OF THE TRANSFORMATION ON THE FRINGE OF JAPANESE CASTLE DOMAINS IN MODERNIZATION
}

A study on the boundary meanings in the fringe of Japanese castle domains (Part 1)

朝井美 樹*, 永瀬 智 基**, 久野 紀 光***

Miki ASAI, Tomoki NAGASE and Toshimitsu KUNO

\begin{abstract}
This study aims to clarify the diachronic channels of the transformation on the fringes of 12 Japanese castle domains with focusing 5 ages among the term which is from Modernization to present age. As the method of the first step to achieve this aim, following three viewpoints are applied to all the 60 moats of the 5 ages of each 12 fringes.

(1):the maintained situation and configuration situation of the ruins on the each bank of all moats

(2):the main form-type on the each bank of all moats

(3):the combination of form-types on both banks of all moats

And as the second step, having unified the analysis result by three viewpoints above, 17 sorts of forms in the 60 moats are clarified.

Finally, the 12 fringes are arranged using 17 sorts of these forms and 4 models of the diachronic channels about the transformation on the fringes of 12 Japanese castle domains are came to clarify as the conclusion.
\end{abstract}

Keywords : Japanese castle domains, Moats, Fringes, Diachronic channels, Spatial typology 城郭, 曲輪, 周縁, 変容過程, 類型

\section{1. 序}

\section{1-1 研究の背景}

我が国における中小・大都市の多くは近世城下町が発展して今日 に至っていることは先学注1) より明らかで、近世城下町としての共 通の出発点を持つ都市の形成過程をみることは現代における都市を 考察する上で重要な意義をもっていると考えられる。

ところで、城下町の核であった城郭は立地環境や歴史的経緯の違 い等により千態万状であるが、すべての城郭に通有の要素として周 縁に迴らされた堀や土塁・石垣、河川といった構築物が挙げられる。 これらは、近世には軍事的防御策としての機能以外に、土地利用の され方や侍・町人の棲み分けを秩序づけるために曲輪を画定する境 界としての役割を担っていた注 2 )。この境界性は地域制の崩壊ととも に必要の意義を失ったと言えるがその現状と変容の過程は明らかで はない。さて、そのような興味に触れるにあたって、城郭の境界性 を担保する堀・土塁等の残存の状況を把握することは不可欠である。 そこで、かつて明確に曲輪を画定していた堀・土塁等注3)の形態的な 残存状況から、明治維新や戦災、高度経済成長といった我が国の近
代から現代までの都市改編下における個々の城郭の曲輪の変容を整 理し、通時的にその履歴を理解することは、城郭の今日的な境界性 を理解する上での基礎的知見となり得ると考えられる。

\section{1-2 研究の目的と方法}

たとえば図 1 のように、郭外側の土塁は取り壊されて街区となっ ているが郭内側の堀は近世のまま保持されているもの、またはその 内外が正反対の様相を呈しているものなどもあり、城郭の曲輪の両 岸は同様の変容をみせるわけではない。このように幅員をもった曲 輪の変容を理解するためには、曲輪の両岸を郭内側と郭外側に分け て個別に履歴を分析・検討していく必要があると考えられる。以上 より、本研究では近世に存在していた曲輪の各岸の履歴を精査する ことを通じて城郭周縁の変容過程を明らかにすることを目的とする。 なお対象年代とする $1900 、 1930 、 1960 、 1990 、 2010$ 年注4) の 5 年 代における日本の城郭 12 城郭注 5)、計 60 資料(図 2)を分析単位とす ることで統一基準による客観的な残存状況の評価を施し、これらを 基に変遷を理解する。また 1900 1930 年を I 期、1930 1960 年を II 期、1960 1990 年を IIII期、1990 2010 年をIV期とし分析を進める。

\footnotetext{
$*$ 名古屋市立大学大学院芸術工学研究科 博士前期課程 $\cdot$ 学士 (芸術工学)

** 名古屋市立大学大学院芸術工学研究科 博士後期課程 $\cdot$ 修士 (芸術工学)

*** 名古屋市立大学大学院芸術工学研究科 准教授・博士 (工学)
}

Graduate Student, Graduate School of Design \& Architecture, Nagoya City University Graduate Student, Graduate School of Design \& Architecture, Nagoya City University Assoc. Prof., Faculty of Design \& Architecture, Nagoya City University, Dr. Eng. 


\section{1-3 既往研究}

現在まで近世城郭・城下町に関する研究は多岐にわたっておこな われており、これに関する文献も非常に豊富である。その多くは歴 史文化的、考古学的な視点からの研究が主であるが、都市・空間学 的な研究も戦前頃から行われてきた注 6$)$ 。その中でも複数の城郭の 変容を把握し比較検討を行なった研究として例えば矢守の城下町プ ランの研究注 7) があげられる。この論考において矢守は、成立期の 違いによって城下町の構造が異なるだけでなく、成立期・完成期・ 崩落期と同一の城郭においてもその時期によって都市構造に変容が みられるとしており、それらの変容過程を城郭どうしで比較し、類 型化を試みている。これは城下町や城郭における変容を把握する点 で本研究と近しい着眼点を有しており、本研究を論じる上での基礎 的研究である。しかし、この研究では城下町が成立する中世末期か ら昭和初期までの変容を分析の対象としており、それ以降の変容過 程についての論考は充分とはいえない。そこで、明治期を含めた近 代から現在に至る城郭空間の変容へ注視を向ける本研究は、既往の 研究からの発展性・独自性を有していると考えられる。

\section{2. 遺構の囲繞形状}

先述の通り、近世では城郭周縁を囲う曲輪によって物的に城郭の 領域を画定していたが、曲輪は堀や土塁といった多重の要素の複合 によって形成されており、今日ではそれらの残存状況はさまざまで ある。そこで本章では次章からの分析に先立ち、かつて城郭領域を 囲繞した曲輪の経年変化を片岸ごとに分けて検討する。

まず、全 60 資料の曲輪両岸に対し、郭内側の際を郭内輪郭線、 郭外側の際を郭外輪郭線と定義する。各々の輪郭線上の堀や土塁、 石垣といった遺構がある部分を抽出し、この分布を囲繞性の有無と その形状の観点から概観した結果、[輪郭線の全周またはほぼ全周に 遺構があるもの (囲繞) ]、[輪郭線のほぼ半周程度に遺構があるもの (半囲繞) $] 、[$ 断片的に遺構があるもの (断片) $] 、[$ 全く遺構がない
もの（遺構無し）］の 4 種注 8) として大別することができた(表 1 )。

これより、郭の内外ともに断片が最多で郭内側：19/60 資料、郭 外側 : $23 / 60$ 資料)、次いで半囲繞(郭内側 : $17 / 60$ 資料、郭外側 : 20/60 資料)、囲繞(郭内側：15/60 資料、郭外側：14/60 資料)であること がわかる。また、この囲繞、半囲繞、断片の該当数は郭内側と郭外 側を比しても特徵的な偏りはみられなかった。

さらに、郭内側と郭外側の遺構の囲繞形状の組合せをみると(表 2)、 i 〜 ix の 9 種が看取された。該当数に着目寸ると、viii : 断片一 断片(14/60 資料)、ｉ：囲繞一囲繞(12/60 資料)、iv：半囲繞一半囲 繞(12/60 資料)が多く、遺構の囲繞形状は郭内側と郭外側で同様の形 態を採る傾向(38/60 資料)にあることがわかった（表 2 太枠部）。

\section{3. 輪郭線の残存状況}

前章では城郭周縁の輪郭線上に残存する遺構にのみ着目してその 平面形状の観点から分析を行ったが、遺構の有無の双方を総じた輪 郭線各部についての分析がなされていない。ところで、全 60 資料 の郭内輪郭線、郭外輪郭線を概観すると、前章で対象とした「遺構 によって物的に輪郭線が保持されている部分（郭内：A、郭外：a とする)」の他に、「遺構はないが街区の境界として輪郭を残してい る部分（郭内：B、郭外：b とする）」と、「輪郭線とは無関係に街 区や街路が敷かれるなどして、その輪郭線を視認できない部分（郭 内：C、郭外：c とする）」の 3 種によって各部を判読できる（表 3 ）。

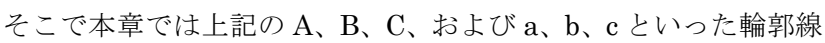
各部の状況を残存形と定義し、全 60 資料の曲輪の状態を把握する。

\section{3-1 主要な残存形}

先に述べたように、近世に存在した曲輪の両岸は内外各々 3 種の 残存形を指標にして判読できる。しかし、例えば 1900 年代におけ る松本城は、郭内側では A,B,C の 3 種で構成されているが、その占 有状況に着目してみると輪郭線の周の多くを $\mathrm{A} の$ 残存形が占めてい る一方で、1930 年代では 1900 年代と同様に A,B,C の残存形で構成

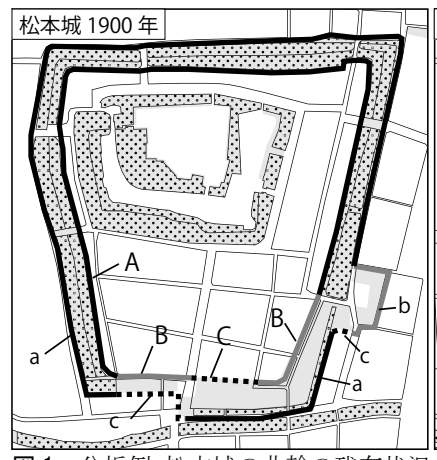

図 1 分析例 松本城の曲輪の残存状況

表 1 遺構の囲繞形状

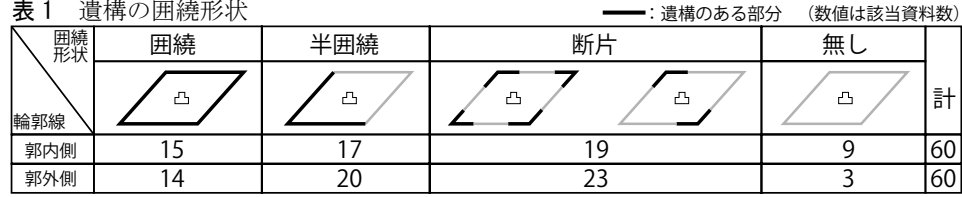

表 2 囲繞形状の内外の組み合わせ

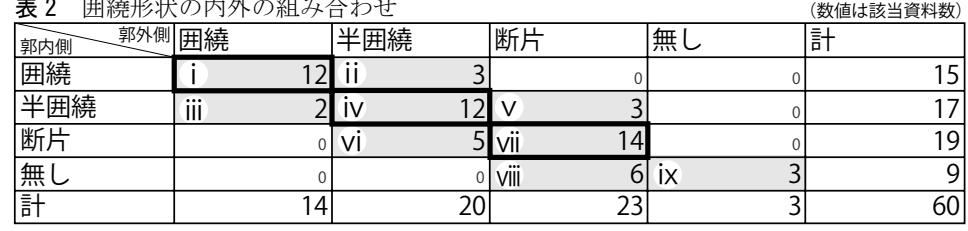

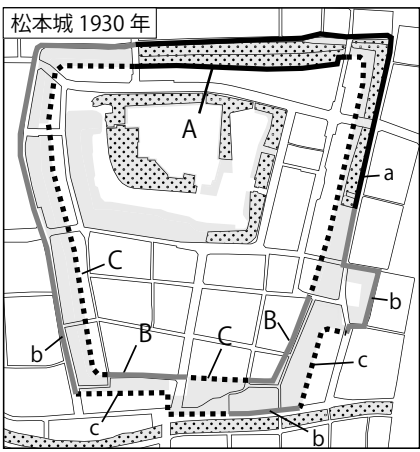

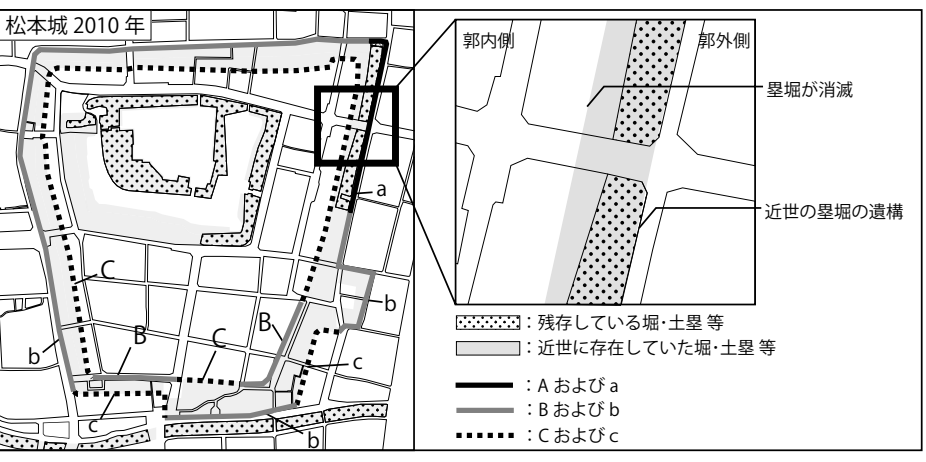

表 3 残存形の種類

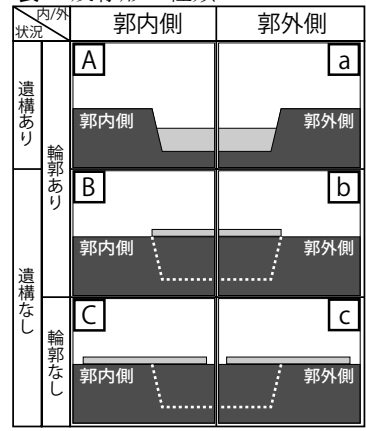

表 4 郭内側の主要残存形

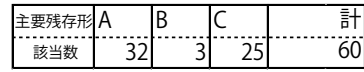

表 5 郭外側の主要残存形 \begin{tabular}{|l|l|l|l|l|}
\hline 主要残存刑 $a$ & $a \cdot b$ & $b$ & $c$ & 計 \\
\hline
\end{tabular}

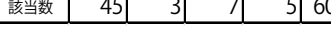
表 6 主要残存形の内外の組合せ

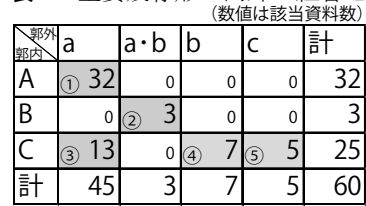




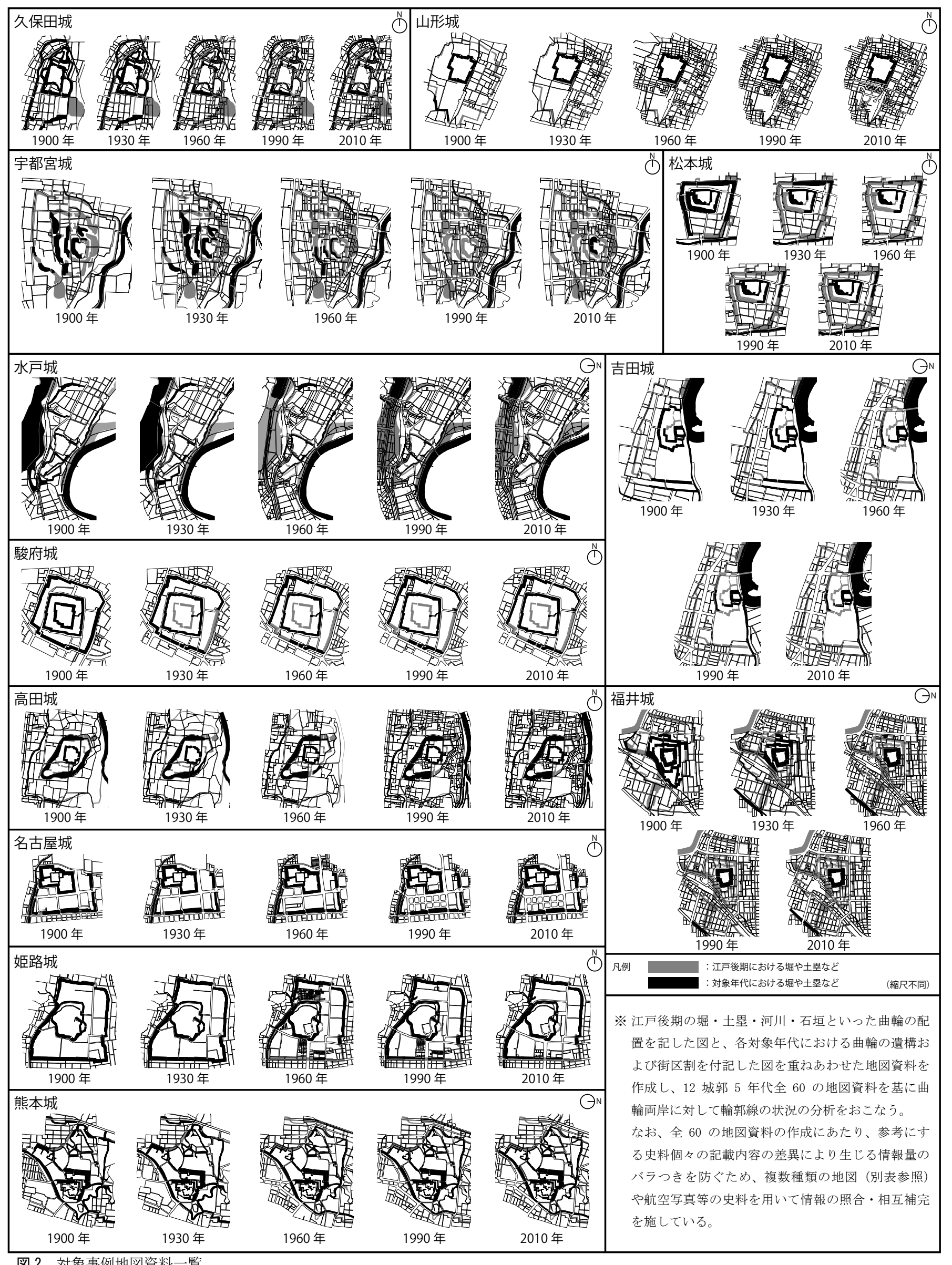

図 2 対象事例地図資料一覧 
されているものの、堀の埋め立てや土塁の取り壊しなどによって大 部分の遺構が消滅したことで $\mathrm{A} の$ 残存形の部分が大幅に減少し、代 わりに C が占有的な残存形となっている（図1)。このように、曲 輪の状況を理解する際に単純に残存形の有無のみによって捉えるこ とに加え、輪郭線を占める主要な残存形の状況を加味することが必 要である。そこで、本節では輪郭線において主要な残存形注 9 ) (以下、 主要残存形とする)を郭の内外側の各々で抽出し、分析を進める。

まず、全資料の郭内輪郭線及び郭外輪郭線それぞれにおいて、主 要残存形を抽出し統計を施した。表 4 より郭内側では全資料は A で あるもの、Bであるもの、Cであるもののいずれかのみの 3 種に限 られ、複数の残存形が拮抗して主要をな寸ものはなかった。また、 該当数に着目すると Aを主要残存形とするものが約半数ともっとも 多く $(32 / 60$ 資料)、次いで $\mathrm{C}$ の該当数が多かった $(25 / 60$ 資料)。それ に比してBを主要残存形とするものはごく少数であった( $3 / 20$ 資料)。 一方、郭外側では $\mathrm{a}$ であるもの、 $\mathrm{b}$ であるもの、 $\mathrm{c}$ であるもの、 $\mathrm{a}$ と $\mathrm{b}$ が拮抗して主要な残存形をなしているものの 4 種が看取された(表 5 )。この 4 種の該当資料数の内訳をみると a を主要残存形とするも のが最も多く (45/60 資料)、その他の $\mathrm{b}(7 / 60$ 資料)や $\mathrm{c}(5 / 60$ 資料)、 $\mathrm{a} \cdot \mathrm{b}(3 / 60$ 資料)のものは少数であった。

以上より、郭内側では主要残存形が A であるものと Cであるもの、 すなわち輪郭線の主が遺構によるものと、輪郭線が主に消滅してい るものの 2 種に分かれる傾向があるが、対して郭外側ではほとんど 多くの資料において主要残存形が a、すなわち輪郭線が主に遺構を 多く残しており、輪郭線の消滅が主立つことはあまりみられなかっ た。すなわち、郭内側に比して郭外側の方が遺構を保持しているも のが多いという傾向がみてとれた。

また、郭内側と郭外側の主要残存形の組合せは(1)〜(5)の 5 種の系 統にまとめられる(表 6 )。(1) : A-a の組みがもっとも多く(32/60 資 料)、次いで(3)：C-a の組み(13/60 資料)であった。その他(4)：C$\mathrm{b}$ の組み(7/60 資料)、(5) : $\mathrm{C}-\mathrm{c}$ の組み(5/60 資料)、(2) : $\mathrm{B}-\mathrm{a} \cdot \mathrm{b}$ の 組み $(3 / 60$ 資料)がみられたが、いずれも該当数は少数であった。以 上のことから、郭内輪郭線の主要残存形が $\mathrm{A}$ 、寸なわち輪郭線が主 に遺構によるものである全 32 件の場合、郭外輪郭線の主要残存形 はすべて a、すなわち輪郭線が主に遺構によるものである。しかし 一方で、郭外輪郭線の主要残存形が a、すなわち輪郭線の主が遺構 によるものである全 45 件の場合、必ずしも郭内輪郭線の主要残存 形が A、すなわち主要残存形が主に遺構によるものであるとは限ら ず (32/45 資料)、主要残存形が C、すなわち輪郭線が消滅してしま っているものとの 2 種の組合せに分かれる傾向がみてとれた。

\section{3-2 両岸の組合せでみた残存形とその組成}

前節までの分析では、郭内輪郭線および郭外輪郭線の両者の対岸 状況を捨象した個別の分析結果として内外の組合せをみることで各 資料を捉えてきた。しかし、実際に並走している郭内輪郭線と郭外 輪郭線の様相を理解するためには、対岸どうしの輪郭線がどのよう な向かい合い方をしているのかという観点が不足している。そこで 本節では、向かい合う両岸どうし、内外各々 3 種の残存形の組合せ (以降、両岸残存形と寸る) から $\mathrm{A}+\mathrm{a} \sim \mathrm{C}+\mathrm{c}$ の 9 種の両岸残存形と して輪郭線の各部を捉え、これら 9 種を遺構の有無や輪郭線の有無 の観点から以下の 3 種のカテゴリに大別した。すなわち、「い: 両 岸もしくは片岸において遺構による輪郭線である部分 $(\mathrm{A}+\mathrm{a} 、 \mathrm{~A}+\mathrm{b}$ 、
表 7 両岸残存形とそのカテゴリ分類

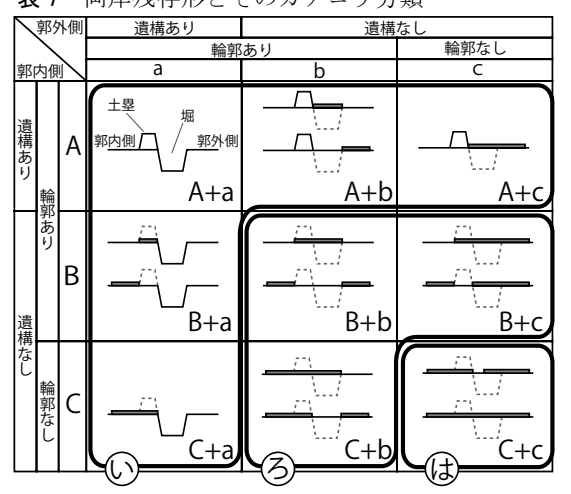

表 8 両岸残存形の組成

表 9 曲輪の残存状況一覧

\begin{tabular}{|c|c|c|c|c|c|c|c|c|c|c|c|c|c|c|c|}
\hline \multirow[t]{3}{*}{ 資料名 } & \multicolumn{3}{|c|}{ 囲繞形状 } & \multicolumn{3}{|c|}{ 主要残存形 } & \multicolumn{9}{|c|}{ 両岸残存形の組成 } \\
\hline & \multirow{2}{*}{\begin{tabular}{c|} 
郭内 \\
輪郭線
\end{tabular}} & \multirow{2}{*}{$\begin{array}{c}\text { 郭外 } \\
\text { 輪郭線 }\end{array}$} & \multirow{2}{*}{ 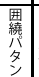 } & \multirow{2}{*}{\begin{tabular}{|c|}
$\begin{array}{c}\text { 郭内 } \\
\text { 輪郭線 }\end{array}$ \\
\end{tabular}} & \multirow{2}{*}{$\begin{array}{c}\text { 郭外 } \\
\text { 輪郭線 } \\
\end{array}$} & \multirow{2}{*}{ 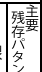 } & & & & & & & & & \\
\hline & & & & & & & & $\overline{\mathrm{A}+\mathrm{b} \mid}$ & & $3+a \mid c+a$ & & $\frac{3}{B+C C}$ & & \begin{tabular}{|l|} 
は \\
$C+c$
\end{tabular} & \\
\hline 久保田1900 & 囲繞 & 囲繞 & i & A & & (1) & 0 & & 0 & 0 & 0 & & 0 & & 1 \\
\hline 久保田1930 & 半囲繞 & 半囲繞 & iv & A & & (1) & 0 & 0 & 0 & 0 & 0 & & 0 & & \\
\hline 久保田1960 & 断片 & 半囲繞 & vi & B & $a \cdot b$ & (2) & & 0 & 0 & & 0 & & 0 & 0 & 丁 \\
\hline 久保田1990 & 断片 & 半囲繞 & vi & B & $a \cdot b$ & (2) & & 0 & 0 & 00 & 0 & & 0 & 0 & J \\
\hline 久保田2010 & 断片 & 半囲繞 & vi & $\mathrm{B}$ & $a \cdot b$ & (2) & & 0 & 0 & 00 & 0 & & 0 & 0 & ア \\
\hline 山形1900 & 断片 & 断片 & vii & $\bar{c}$ & & c(5) & 0 & & & & & 0 & 0 & O & $\bar{\gamma}$ \\
\hline 山形1930 & 断片 & 断片 & vii & c & & c) (5) & 0 & & & & 0 & 0 & 0 & 0 & 厂 \\
\hline 山形1960 & なし & なし & ix & c & & c) (5) & & & & & 0 & 0 & 0 & 0 & 才 \\
\hline 山形1990 & なし & なし & ix & c & & c) (5) & & & & & 0 & 0 & 0 & 0 & 才 \\
\hline 山形2010 & なし & なし & ix & $c$ & & c) (5) & & & & & 0 & 0 & 0 & 0 & 才 \\
\hline 宇都宮1900 & 断片 & 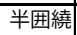 & vi & $\mathrm{C}$ & & (3) & 0 & & $\bar{O}$ & 00 & & 0 & O & $\bar{O}$ & $\bar{J}$ \\
\hline 宇都宮1930 & 断片 & 半囲繞 & vi & c & & a (3) & 0 & & 0 & 00 & & 0 & 0 & 0 & J \\
\hline 宇都宮1960 & なし & 断片 & viii & c & & (3) & & & & & & 0 & 0 & 0 & J \\
\hline 宇都宮1990 & なし & 断片 & viii & c & & (3) & & & & 00 & & 0 & 0 & 0 & J \\
\hline 宇都宮2010 & なし & 断片 & viii & C & a & (3) & & & & 00 & & O & 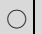 & 0 & テ \\
\hline 水戸1900 & 半囲繞 & 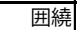 & iii & $\vec{A}$ & $\bar{a}$ & a(1) & 0 & & $\bar{O}$ & O & & & 0 & & イ \\
\hline 水戸1930 & 半囲繞 & 囲繞 & iii & $A$ & & (1) & 0 & & O & 0 & & & 0 & & イ \\
\hline 水戸1960 & 断片 & 断片 & vii & c & & (3) & 0 & 0 & 0 & 00 & 0 & & 0 & 0 & J \\
\hline 水戸1990 & 断片 & 断片 & vii & $c$ & & a (3) & 0 & & 0 & & 0 & & 0 & 0 & J \\
\hline 水戸2010 & 断片 & 断片 & vii & c & & (3) & 0 & & 0 & 00 & 0 & & 0 & 0 & T \\
\hline 松本1900 & 囲繞 & 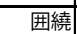 & $\mathrm{i}$ & $\bar{A}$ & a & (1) & $\bar{O}$ & & & 00 & & O & O & & T \\
\hline 松本1930 & 断片 & 断片 & vii & C & b & (4) & 0 & & & 0 & 0 & $\bigcirc$ & 0 & 0 & フ \\
\hline 松本1960 & なし & 断片 & viii & c & $b$ & (4) & & & & O & O & 0 & 0 & & 1 \\
\hline 松本1990 & なし & 断片 & viii & c & b & (4) & & & & 0 & 0 & 0 & 0 & & 1 \\
\hline 松本2010 & なし & 断片 & viii & $c$ & b & (4) & & & & 0 & 0 & 0 & 0 & & 1 \\
\hline 駿府1900 & \begin{tabular}{|l} 
囲繞 \\
\end{tabular} & \begin{tabular}{|l|l} 
囲繞 \\
\end{tabular} & $\bar{i}$ & $\bar{A}$ & a & (1) & 0 & & & & & & & & $\bar{I}$ \\
\hline 駿府1930 & 囲繞 & 囲繞 & $\mathrm{i}$ & A & & a (1) & 0 & & & & & & 0 & & 1 \\
\hline 駿府1960 & 半囲繞 & 半囲繞 & iv & $A$ & a & (1) & 0 & 0 & & 0 & & & 0 & & 1 \\
\hline 駿府1990 & 半囲繞 & 半囲繞 & iv & $A$ & a & (1) & 0 & 0 & & & & & 0 & & イ \\
\hline 駿府2010 & 半囲繞 & 半囲繞 & iv & $A$ & a & (1) & 0 & 0 & & & & & 0 & & 1 \\
\hline 高田1900 & 半囲繞 & \begin{tabular}{|c|} 
半囲繞 \\
\end{tabular} & iv & $\bar{A}$ & a & $\begin{array}{l}a(1) \\
\end{array}$ & 0 & & & 00 & & & & 0 & r \\
\hline 高田1930 & 半囲繞 & 半囲繞 & iv & $A$ & a & (1) & 0 & & & & & & & 0 & ウ \\
\hline 高田1960 & 半囲繞 & 半囲繞 & iv & A & a & (1) (1) & 0 & & & & & & & 0 & ウ \\
\hline 高田1990 & 半囲繞 & 半囲繞 & iv & A & a & a (1) & 0 & & & & & 0 & & 0 & T \\
\hline 高田2010 & 半囲繞 & 半囲繞 & iv & $A$ & a & (1) & 0 & & & 00 & & 0 & & 0 & T \\
\hline 福井1900 & 断片 & 断片 & vii & $\mathrm{c}$ & $a$ & (3) & 0 & $\bar{O}$ & O & 00 & O & & O & $\bar{O}$ & $\bar{J}$ \\
\hline †1930 & 断片 & 断片 & vii & c & a & a (3) & 0 & 0 & 0 & 00 & 0 & & O & 0 & T \\
\hline 牛1960 & 断片 & 断片 & vii & c & a & a (3) & 0 & & & 00 & 0 & 0 & O & 0 & T \\
\hline 井1990 & 断片 & 断片 & vii & c & a & (3) (3) & 0 & & & 00 & 0 & 0 & O & 0 & J \\
\hline 福井2010 & 断片 & 断片 & vii & $c$ & a & (3) & 0 & & & 00 & 0 & 0 & 0 & 0 & J \\
\hline 名古屋1900 & 囲繞 & 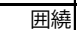 & & A & & $\begin{array}{l}\text { 日 (1) } \\
\end{array}$ & 0 & & & $\bar{O}$ & & & & & I \\
\hline 名古 & 囲繞 & 囲繞] & 1 & & & (1) & 0 & & & 0 & & & & & J \\
\hline 名古屋1960 & 囲繞 & 囲繞 & $\mathrm{i}$ & A & a & (1) & 0 & & & 0 & & & & & I \\
\hline 屋1990 & 囲繞 & 繞 & $\mathrm{i}$ & $A$ & a & (1) & 0 & & & 0 & & & & & I \\
\hline 名古屋2010 & 囲繞 & 囲繞 & $\mathrm{i}$ & A & a & (1) & 0 & & & 0 & & & & & I \\
\hline 吉田1900 & $\begin{array}{l}\text { 半囲繞 } \\
\end{array}$ & 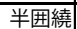 & iv & $\bar{A}$ & & (a) (1) & O & & & & & & & $\bar{O}$ & $\overline{7}$ \\
\hline & 半囲繞 & 半囲繞 & iv & A & a & (1) & 0 & & & & & & O & 0 & J \\
\hline & 断片 & 断片 & vii & c & b & (4) & 0 & & & & 0 & & 0 & 0 & J \\
\hline 吉 & 断片 & 断片 & vii & c & b & (4) & 0 & & & & 0 & & 0 & 0 & J \\
\hline 吉田2010 & 断片 & 断片 & vii & c & b & (4) & 0 & & & & 0 & & 0 & 0 & T \\
\hline 姫路1900 & $\begin{array}{l}\text { 囲繞 } \\
\end{array}$ & \begin{tabular}{l|} 
囲繞 \\
\end{tabular} & $\bar{i}$ & $\bar{A}$ & & $\begin{array}{ll}a & (1) \\
\end{array}$ & 0 & & & & & & & & 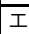 \\
\hline 姫路1930 & 囲繞 & 囲繞 & 1 & A & a & (1) & 0 & & & & & & & & \\
\hline 姫路1960 & 半囲繞 & 半囲繞 & iv & A & a & (1) & 0 & 0 & & 0 & & 0 & 0 & 0 & J \\
\hline 路1990 & 囲繞 & 半囲繞 & ii & A & a & (1) & 0 & 0 & & & & & 0 & 0 & 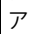 \\
\hline 姫路2010 & 囲繞 & 半囲繞 & $\mathrm{ii}$ & A & $a$ & (1) & 0 & 0 & & & & & 0 & 0 & 厂 \\
\hline 本190 & $\begin{array}{l}\text { 囲繞 } \\
\end{array}$ & 囲繞 & & A & & $\begin{array}{ll} & (1) \\
\end{array}$ & 0 & & & & & & & & \\
\hline 本1930 & 囲繞 & 半囲繞 & ii & $A_{-}$ & & (1) & 0 & 0 & & & & & & & \\
\hline \$1960 & 半囲繞 & 断片 & $\mathrm{v}$ & A & a & a (1) & 0 & 0 & & & & & & 0 & $r$ \\
\hline 本1990| & 半囲繞 & 断片 & $\mathrm{v}$ & A & & (1) (1) & 0 & 0 & & & & & & 0 & ウ \\
\hline 熊本2010 & 半囲繞 & 断片 & v & A & a & (1) & 0 & 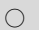 & & & & & & & \\
\hline
\end{tabular}


表 10 残存状況の構成類型

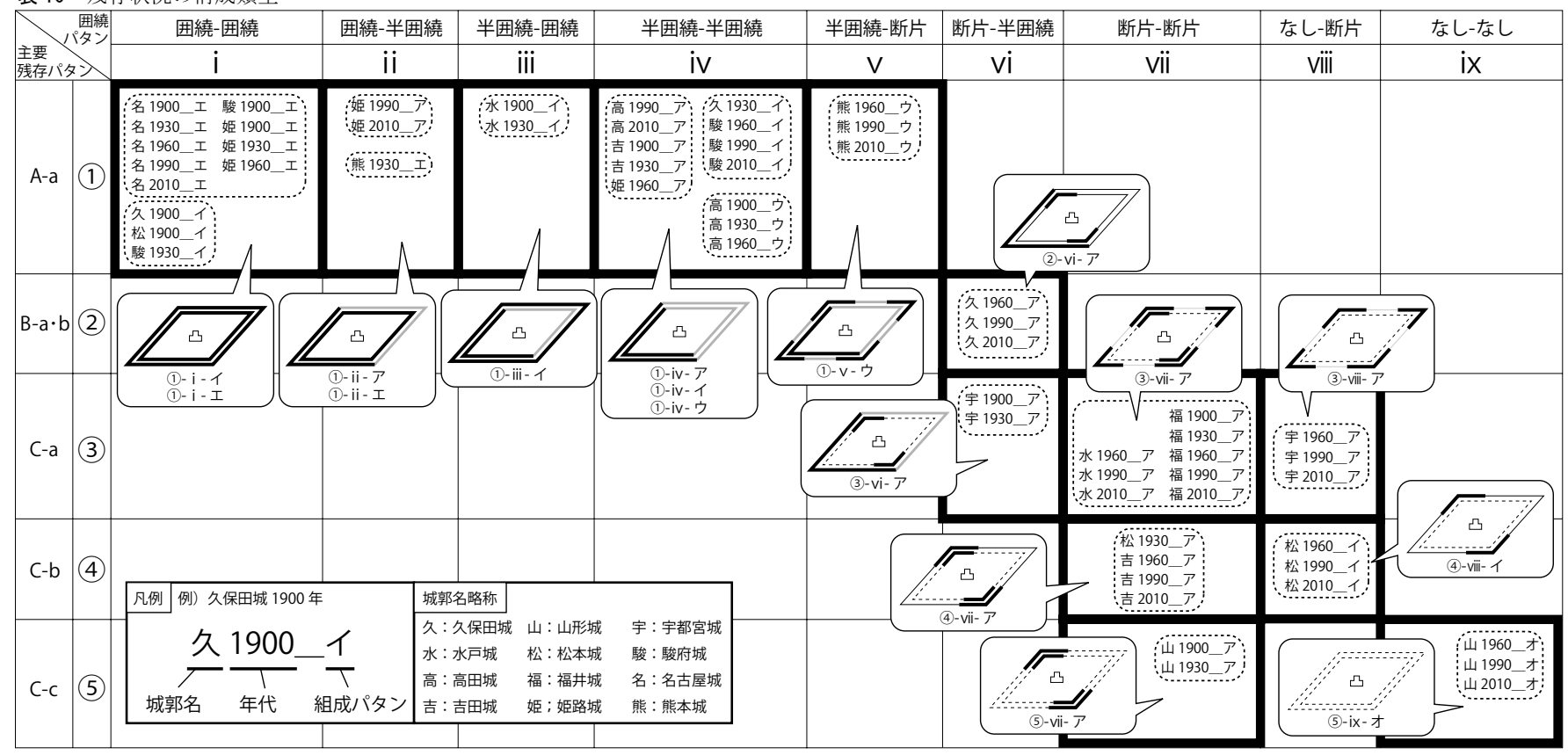

$\mathrm{A}+\mathrm{c} 、 \mathrm{~B}+\mathrm{a} 、 \mathrm{C}+\mathrm{a}) 」 、 「 ろ:$ 両岸のどちらにも遺構による輪郭線は存 在していないが、両岸もしくは片岸において街区等の境界として輪 郭線が残存している部分 $(\mathrm{B}+\mathrm{b} 、 \mathrm{~B}+\mathrm{c} 、 \mathrm{C}+\mathrm{b})$ 」、「は：両岸のどちら

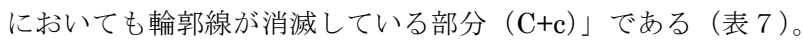

これら 3 種のカテゴリの該当状況を全 60 資料にて確認し、カテ ゴリの組合せを整理したものが表 8 である。結果として、「ア：い〜 は、の全カテゴリによって輪郭線を構成しているもの」、「イ：い、 ろ、の二種のカテゴリで輪郭線を構成しているもの」、「ウ:い、は、 の二種のカテゴリで輪郭線を構成しているもの」、「エ：い、のみの カテゴリで輪郭線を構成しているもの」、「オ：ろ、は、の二種のカ テゴリで輪郭線を構成しているもの」、の 5 種のパタンが看取され た（以降、これらを組成パタンと寸る）。また、これら組成パタンの 該当数に着目すると、アがもっとも多く (29/60 資料)、次にイ $(12 / 60$ 資料)、エ $(10 / 60$ 資料)、ウ $(6 / 60$ 資料)、才 (3/60 資料) とつづ いた。アが全資料の約半数を占めていることから、遺構による輪郭 線がある部分、街区等の境界による輪郭線がある部分、輪郭線がな い部分、といった 3 種の組成パタンの併存が多いことがわかる。ま た、「い」のみの組成である組成パタン・エの該当数は少数であり、 かつ「ろ」のみの組成や「は」のみの組成はみられなかったことか ら、単数カテゴリによる組成であるものは僅少であるといえる。

\section{4. 輪郭線の残存状況の構成類型の抽出}

前章までに各々検討した遺構の囲繞形状、主要残存形、両岸残存 形の組成の指標を総合したものが表 9 である。これを基に縦軸に主 要残存形の内外の組合せ(1)〜 (5)系統を、横軸に囲繞形状の内外の組 合せ $\mathrm{i} \sim \mathrm{ix}$ を据えて整理した結果 (表 10 ) 、まず 13 種の類型が抽 出された (表 10 太枠部)。さらに両岸残存形の組成を加味すること によって 17 種の構成類型を導いた(表 10 点線枠部)。

(1)系統に分類される (1)- i 〜 (1)- v は郭内側、郭外側ともに輪郭線 が主に遺構として残っているものである。(1)- i は郭内側、郭外側と もにほぼ全周に遺構が残存しているものであり、組成パタンがイで
ある(1)- i ーイと組成パタンがエである(1)- i -エの 2 種がある。 (1)- ii は郭内側が環状に、郭外側では半周程度を遺構が廻っているもので、 組成パタンがアである (1)- ii -アと組成パタンがエである(1) - ii -エの 2 種にさらに分類される。(1)-iii は(1)- ii と反対に、郭内側に半周程度、 郭外側は環状に遺構が廻っているという構成をもつものであり、組 成パタンはイであるため (1)- iii-イと表記する。(1)-iv は郭内側、郭外 側ともに半周程度遺構が迴る構成であり、組成パタンがアである (1)iv-ア、イである (1)-iv-イ、ウである (1)-iv-ウの 3 種で構成されてい る。(1)- v は郭内側においては半周程度遺構が廻り、郭外側では大き くまとまって連続的に遺構が残存するのではなく断片的に遺構を残 すという構成をとるものである。この型の組成パタンはおしなべて ウであるので(1) - v-ウと表記する。

(2)系統の類型(2)-vi は郭内輪郭線において断片的に遺構があるも のの輪郭線は主に街区等による境界であり、郭外側では半周ほどの 遺構がある部分と街区等の境界となる部分が同程度みられるもので ある。また、組成パタンはアであるもののみであり (2)-vi-アと記す。

(3)系統から (5)系統に属する類型(3)-vi〜 (5)-ix は郭内輪郭線が主に 消滅しているもので、そのうち郭外輪郭線の主な部分に遺構が残っ ているものが(3)-vi (3)-viii、街区等の境界としてかたちを変えて残っ ているものが(4)-vii、(4)-viii、郭外輪郭線においても主な輪郭線が消 滅しているものが(5)-vii、(5)-ixである。(3)-vi は郭内側において断片 的に、郭外側においては半周ほど連続的に遺構を残す構成で、(3)viïは両岸とも断片的な遺構を残しているものである。また(3)-viiil郭 外側では断片的に遺構を残しているものの、郭内側においては一切 の遺構を残していない。また、(3)系統の類型は組成パタンがおしな ベてアの型であるためそれぞれを(3)-vi-ア、(3)-vii-ア、(3)-viii-アと表 される。(4)-vii は郭内側、郭外側ともに断片的な遺構をもつもので、 かつ組成パタンはアである。(4)-viiil郭外側に断片的な遺構をもつも のの、郭内側においては一切の遺構を残していないという構成のも のであり、組成パタンはイであった。(5)-vii は郭内側、郭外側ともに 断片的な遺構の残存がみられるもの、(5)- ix は郭内側、郭外側ともに 
一切の遺構を残していないものである。(5)-vii は組成パタンがア、(5) - ix は組成パタンがオという型であった。

以上、郭内輪郭線、郭外輪郭線のそれぞれの、主な残存形、遺構 の囲繞形状のあり方、両岸残存形の組成を検討寸ることで 17 の残 存状況の構成類型を抽出することができた。

\section{5. 曲輪の残存状況の変遷}

前章で得られた 17 種の残存状況の構成類型から城郭ごとの変遷 をまとめ（表 11 ）、各々の城郭における曲輪の変容履歴を把握し、 さらに全 12 城郭の変容履歴における共通性と差異を明らかにする。

\section{5-1 残存状況の構成類型の変容}

まず、城郭の曲輪が年代の変化に伴ってどのような変容を経てき たのかを理解するために、前後する年代間での残存状況の構成類型 の変容、寸なわち主要残存形、囲繞形状、組成パタンのいずれかが かわるという変容 (以降、類型変容とする) を抽出すると、10 城郭、 全 15 件の類型変容が抽出された（表 11 太線部）。

そこで、城郭ごとの類型変容の回数を分析すると、類型変容の回 数は 0 回、 1 回、2 回の 3 種が看取され、3 回以上の変容をする城 郭はなかった。変容回数が 0 回の城郭は 2 城郭(福井城、名古屋城)、 1 回の城郭は 5 城郭（山形城、宇都宮城、水戸城、高田城、吉田城） 2 回の城郭は 5 城郭（久保田城、松本城、駿府城、姫路城、熊本城） であった。変容回数が 1 回および 2 回の城郭はと同数該当したが (い ずれも $5 / 12$ 城郭)、それに比して変容回数 0 回の城郭は少ないとい える $(2 / 12$ 城郭)。

また、変容の時期に着目すると、0 回変容の 2 城郭を除く、全 10 城郭のうち、9 城郭において II 期に変容が起こっている。また、I 期に変容が起こる城郭は 4 城郭、III期に変容が起こる城郭が 2 城郭 であり、IV期に類型変容がみられる城郭はなかった。これより、1 回変容の城郭ではその曲輪の変容は II 期に起こる傾向にあり、2 回 変容の城郭は II 期の変容と I 期もしくはIII期での変容の組合せによ って捉えることができる。

さらに、これらの類型変容が具体的にどのような変容であったの かを理解するために、変容のあった前後の差異から各々の類型変容 に対して意味付けを行なう（表 11 -付表）。

まず、両岸の主要残存形の変容を伴わない囲繞形状または組成パ タンの変化すなわち同系統（両岸の主要残存形が同一）の類型間の 変容〔同系変容〕か、主要な残存形の変化を伴う異系統（両岸の主 要残存形が不同）の類型間の変容〔異系変容〕かという観点で 2 種 に分類することでその類型変容の規模を把握する。また、同系変容 の場合、両岸の輪郭線が主に遺構である(1)系類型間での変容〔両岸 残存〕と、郭外輪郭線が主に遺構である(3)系類型間での変容〔片岸 残存、、両岸とも遺構が主に消失している(4)系(5)系の類型間での変容 〔両岸僅少残存〕、いう 3 種に区別して捉えることができる。異 系変容も同様の視点で、郭内輪郭線の主にあった遺構は消滅するが 郭外輪郭線の主が遺構によっている状態が継続する (1)系から (3)系一 の変容〔片岸消失〕と、両岸の輪郭線の主にあった遺構が消滅する (1)系から (2)系、(4)系への変容〔両岸消失〕の 2 種の変容として捉え られる。このような分類を 15 件の類型変容に施したところ、同系 変容は（11/15 件)、異系変容（4/15 件）に比して頻発することがわ かった。また、同系変容ついては 11 件中 8 件が(1)系じうしの変容

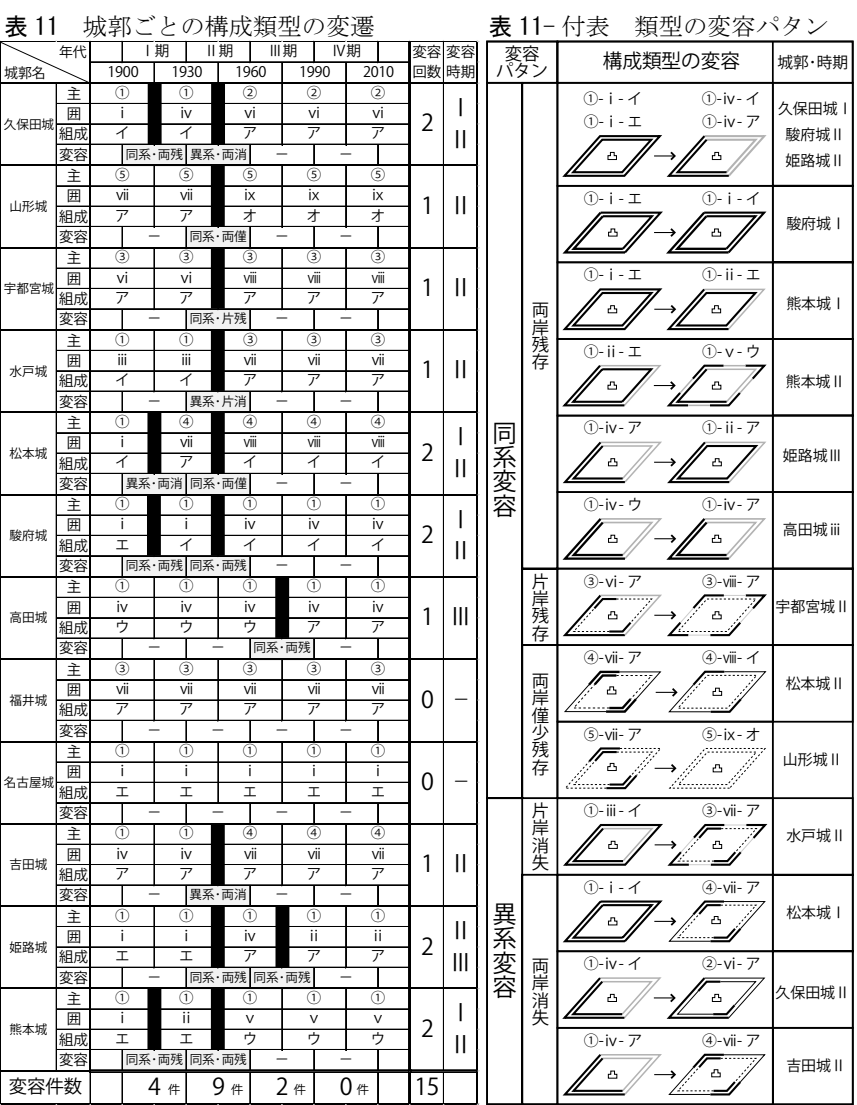

である〔両岸残存〕の変容であり、大半を占めていることがわかっ た。異系変容では〔片岸消失〕が 1 件、〔両岸消失〕が 3 件であり、 〔両岸消失〕への若干の偏りをみてとることができた。

\section{5-2＼cjkstart城郭における曲輪の変遷の型}

前節で分析した観点を照合することで各城郭の曲輪の変遷を性格 付け、さらに城郭どうしの共通性や差異を明らかにする。類型変容 の回数 (図 3 横軸)、類型変容の時期（図 3 中破線部）、類型の変容 パタン（図 3 中太線部および細線部）の 3 つの観点の重ね合せから 城郭の変遷のしかたを性格付ける変遷タイプ 10 種が抽出された。 <変遷タイプ・ら、元、夙、加、き>は類型の変容が 1 回起こる もので、この変容は＜変遷タイプ・ら>を除く、概対すべての城郭 において II 期に起こる。<変遷タイプ・ら>は1 系類型間の変容が 起こるもので、これには高田城が該当した。また、変化時期はIII期 であった。<変遷パタン・园、周>は1系類型から他系類型への異 系変容を伴うものである。中でも<変遷パタン・团〉は〔片岸消失〕 という (1)系類型から (3)系類型への変容であり、郭内輪郭線の主にあ った遺構は大きく消滅するものの、郭外輪郭線においては主であっ た遺構がそのまま維持するという変容が起こる型であり、水戸城が これに該当する。<変遷パタン・か > は(3)系類型間での同系変容が 起こるもので、宇都宮城がこれに該当する。<変遷パタン・き>は (5)系類型間の同系変容が起こるものである。つまり 1900 年時点に おいてすでに両岸ともに輪郭線が消滅しているおり、その類型のま ま現代に継続されるという型で、山形城が該当した。

<変遷パタン・く、け、こ>は、類型の変容回数が 2 回のもので ある。中でも＜変遷パタン・く、け $>$ は 2 回の変容のいずれもが 1 系類型間の同系変容である。 $<<>$ は II 期と III 期に変化がおこり (姫路城が該当)、 <田>は I 期と II 期に変容が起こるもので、駿 


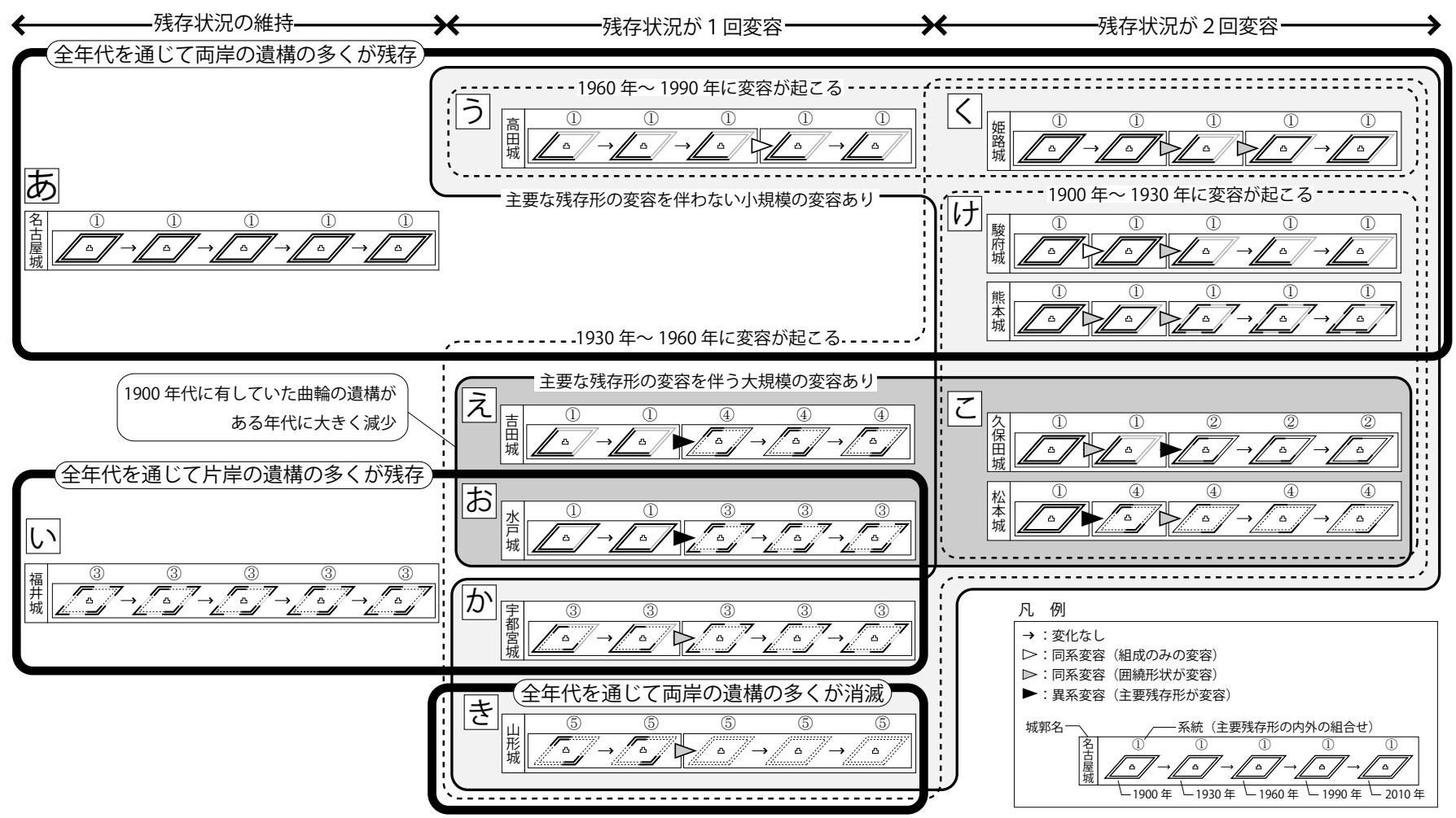

図 3 城郭の曲輪の変遷パタン

府城と熊本城が該当した。＜変遷パタン・モ>は I 期と II 期に変容 があり、変容パタンは同系変容と異系変容が 1 回ずつである。

また、これらの変遷パタンどうしの関係を捉えると、く変遷パタ ン・め、ら、く、田>は類型変容の回数に関わらず「全年代を通じ て両岸の輪郭線の遺構の多くが残存し続ける」という城郭群であり、 また<変遷パタン・い、周、同>は形式変化の回数に関わらず「全 年代を通じて片岸の輪郭線の遺構の多くが残存し続ける」という城 郭群であるといえる。

さらに<変遷パタン・园、周、人は異系変容を伴うものである。 つまり、1900 年代には保持されていた曲輪の両岸の遺構が、<闰、 こ>では両岸において、<团>では片岸において、ある年代で大き く減少するという城郭群であるといえる。

以上、構成類型の変遷として「類型変容の回数」、「類型変容の時 期」、類型の変容パタン」という 3 つの観点の検討を通じて、「全 年代を通じて曲輪の両岸において遺構による輪郭線が多く残存し続 ける型」、全年代を通じて曲輪の片岸において遺構による輪郭線の 多くが残存し続ける型」、「全年代を通じて曲輪の両岸の輪郭線の多 くが消滅している型」といった変容の有無にかかわらず 1900 年〜 現在に至るまで通底する要素の枠組みと、「1900 年代有していた曲 輪の遺構による輪郭線が、ある年代に大きく減少する型」といった 大きく変容した履歴の有無についての枠組みによって城郭の曲輪の 輪郭線の変容を整理することができた。

\section{6. 結}

本研究では、日本の城郭周縁の曲輪の両岸を輪郭線と郭内側と郭 外側に分けて、その遺構の囲繞の形状や、主要な残存形とその組成 から輪郭線の残存状況を検討した。また、それら分析の重㸚あわせ から曲輪の残存状況として 17 の構成類型を抽出した。さらに、城郭
ごとに構成類型の変容の回数やその時期、変容の内容といった観点 で捉え、それらを総合的に検討することで変遷のパタンを抽出した。 その結果、10 種の変遷の型が見出されたが、これらの型を概観し た大きな枠組みとして捉えると、残存形式変化の有無に関わらず「全 年代を通じて曲輪の両岸において遺構による輪郭線が多く残存し続 ける型」、全年代を通じて曲輪の片岸において遺構による輪郭線の 多くが残存し続ける型」、全年代を通じて曲輪の両岸の輪郭線の多 くが消滅している型」といった変容の有無にかかわらず 1900 年〜 現在に至るまで通底する要素の枠組みを把握できた。またこれらの 枠組みと重ねて、「1900 年代有していた曲輪の輪郭線が、ある年代 に大きく減少する型」といった比較的大規模な变容が起こって現代 に至っているものといった枠組みを見出した。

以上、近世の城郭領域が明治から現代に至るまでたどってきた複 数城郭の変容の履歴を精查し、城郭間に存在する共通性と差異を把 握することによって各々の城郭の変容の性格を明らかにした。

ところで、冒頭に述べたように近世の城郭空間において、本稿で 興味対象としたような曲輪という物的境界は軍事的防御の役割を除 くと、侍や町人の棲み分けの地域制や土地利用の仕方を明確にする ための一つの手段であったといえる。しかし、近代から現代にかけ て生じた曲輪の変容が、例えば土地利用の観点における境界性など、 都市骨格においていかなる寄与をしているかは定かではない。本研 究の知見を踏まえて、今後の課題として議論する必要がある。

\section{参考文献}

1) 矢守一彦 : 都市プランの研究, 大明堂, 1970

2) 矢守一彦: 城下町のかたち, 筑摩書房, 1988

3) 矢守一彦: 城下町, 学生社, 1972

4) 矢守一彦 : 城下町ノート, 古今書院, 1972

5 ) 矢守一彦: 日本城郭史研究叢書一城下町の地域構造, 名著出版, 1987

6 ）藤岡通夫 : 城と城下町, 中央公論美術出版, 1988 
7 ) 藤岡謙次郎：城下町とその変貌, 柳原書店, 1983

8 ）小林清治：福島大学学芸学部論集 社会科学一いわゆる「城下町」の構 造, 福島大学学芸学部, 1957

9 ) 小野均: 近世城下町の研究, 至文堂, 1928

10）豊田武：日本の町 その歴史的構造一城下町の機能と構造, 地方史研究協 議会／編, 1958

11）豊田武：日本の封建都市, 岩波全書, 1952

12）材野博司：都市の町割, 鹿島出版, 1989

13）矢崎武夫：日本都市の発展過程, 弘文堂, 1962

14）原田伴彦：中世に於ける都市の研究, 講談社, 1942

15）岡田鎮太 : 近世城下町名古屋, 金城学院大学, 1961

16）伊藤ていじ：城とその町 [再刊],淡交新社, 1963

17）佐藤滋 : 城下町の近世まちづくり, 鹿島出版会, 1995

18）高橋康夫ほか：図集 日本都市史, 財団法人 東京大学出版会, 1993

19）西ヶ谷恭弘：日本名城図鑑, 理工学社, 1989

20）平井聖監修：図説 日本城郭大事典 1 - 3 , 株式会社日本図書ゼ夕一, 2000

21）植野糾ほか：際の都市論, 山海堂, 1996

22）株式会社新創社：城下町時代MA P 関東編, 株式会社 P H P 研究所, 2010

23）株式会社新創社：城下町時代MA P 上方編, 株式会社 P H P 研究所, 2011

24）小松芳郎：松本市 100 年地図帖, しなのき書房, 2007

25) 渡部景一 : 秋田市歴史地図, 無明舎出版, 1984

26）松浦健治郎・二之湯裕久・浦山益郎：戦災復興事業前後における官庁街 の立地と空間構成の変容, 日本建築学会計画系論文集, Vol 71 , No 608, pp. 89-96, 2006. 4 などの一連の研究

注

注 1) 参考文献 1）～16）など

注 2 ）矢守は参考文献 1）p 286 において「地域制一これは (中略) 具体的な画 定線として多くの場合塁堀がもちいられていること、濠には自然の水 系をたくみに改編し利用している」と述べている。

注 3 ) 本稿で扱うのは武家地と町人地の地域制を物理的に画定する外郭の堀 や河川、土塁・石垣といった要素である。例えば姫路城のような惣構 えをもつ城郭においては媰構えを構築する外堀ではなく、武家地を囲 う中堀を対象としている。なお、分析対象とする塁堀よりも城内側の 領域を「郭内」、外側の領域を「郭外」と定義している。

注 4 ) 対象年代は明治維新後の塁堀をみるために 1900 年頃、第二次世界大戦 直前の軍事利用の状況についてを 1930 年頃、第二次世界大戦復興を概 衩果たしたとされる 1960 年頃、バブル経済の都市改編についてをみる ために 1990 年頃を 2010 年現在と合わせた 5 年代を設定することで近 代以降の我が国の歷史的事変に伴う都市改編を追随できると考えられ る。また、それぞれの資料において情報量のバラつきを防ぐために複 数の地図や航空写真等の史料 (別表参照) を用いていることなどから、 各年代における資料は概衫 5〜10 年前後の年代的なズレを許容するも のとする。

注 5 ) 本研究は全国の複数の城郭とその周辺の変遷を相対的に論考するため、 分析対象とする城郭間で著しく都市規模の異ならないように、また、 明治初期での旧城下町の骨格に大きな差異がないように、以下 4 観点 を選定条件とした全 12 城郭を分析対象とした。すなわち、「江戸（東 京）、京都、大坂（大阪）の三都を除く地方城郭であること」「明治 6 年の廃城令にて存城処分となった城郭であること」「現在、政令指 定都市・中核市・特例市のいずれかの都市に立地している城郭である こと」「武家地と町人地を分かつ地域制の境界として機能する堀・鲑 等により城郭領域が囲繞されていた平城または平山城の城郭であるこ と」である。

注 6 ) 参考文献 9 ) なと

注 7 ）参考文献 1）など

注 8 ) 各資料におけるもっとも大きな連続した遺構のまとまり（直行街路等 による分断を除く）を抽出する。その遺構のまとまりが城郭の全周ま たは全周の約 7 割以上を覆っているものを〔囲繞〕、 4 割〜 7 割程度 のものを[半囲繞〕、4割以下のものを〔断片〕とし、一切の遺構が ないものを〔遺構無し〕と定義する。

注 9 ) 残存形 A、B、C (a、b、c) にわけられた輪郭線の各々の総長を算出し、 それが最も大きい残存形を主要残存形とする。また久保田城郭外輪郭 線では残存形 $\mathrm{a}$ と b の差異が $1 \%$ 程度と非常に僅少であったため、拮抗 した主要残存形として「a・b」を抽出した。その他の城郭ではそのよう な例はみられなかった。
別表 参考史料 覧

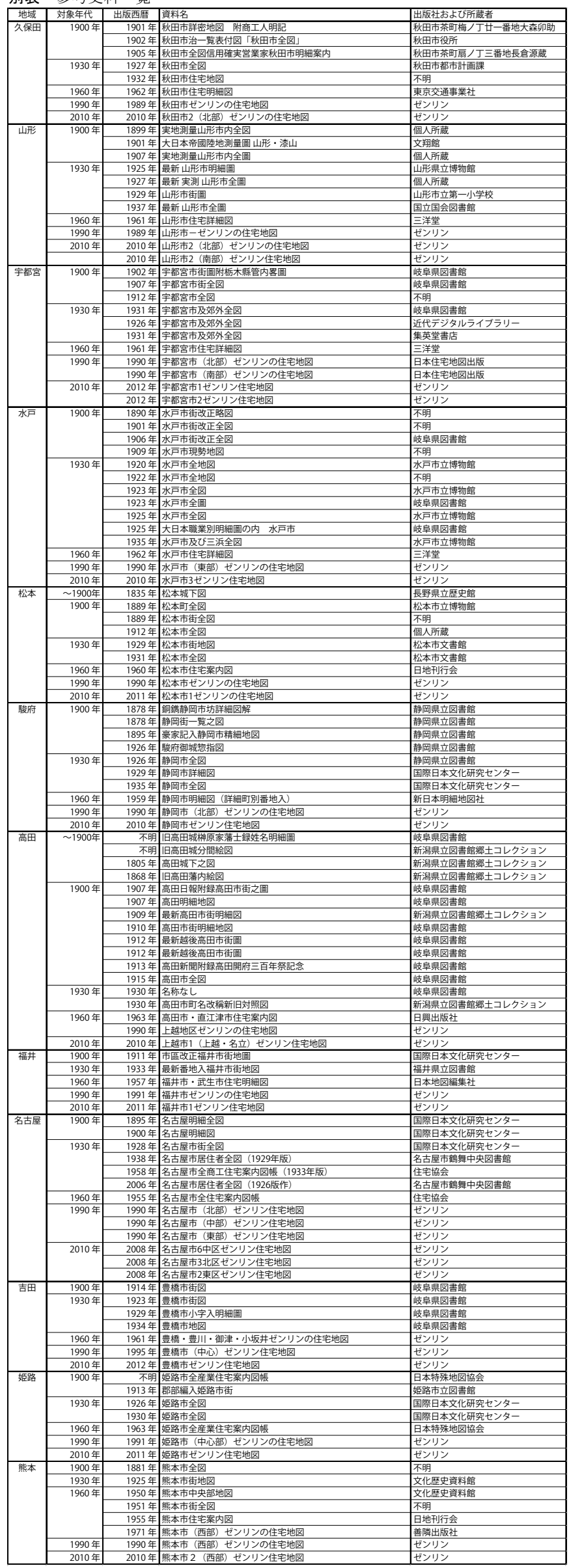

